\title{
AMONG STUDENTS' INTERNAL FACTORS, SHOULD MOTIVATION BE USED AS ONE OF RECRUITMENTS FOR ADMISSION OF MEDICAL STUDENTS IN INDONESIA?
}

\author{
Hikmawati Nurrokhmanti, Mora Claramita, Prattama Santoso Utomo \\ Department of Medical Education, Faculty of Medicine, Universitas Gadjah Mada
}

\begin{abstract}
Background:Indonesian medical education recruitment system recruits students directly from high school who had been influenced by mostly teacher centered learning. As part of pedagogical approach in higher education, those students will be obligatory to learn independently and effectively. Self-directed learning (SDL) is an important aspect in latest medical educational evidence which would determine students' successfulness in learning. Self-directed learning readiness (SDLRS) is influenced by several factors including motivation, age, culture, and previous education experience. Today, the admission process in Indonesia is based on knowledge-test based only. This study aims to reveal correlation between several factors which influence students' Self Directed Learning Readiness (SDLRS).

Methods: This study used SDLRS questionnaire as a valid and reliable tool to measure the students' self directed learning readiness and correlate with those several factors.

Result: From 540 distributed questionnaires, 412 questionnaires returned back. The Spearman correlation showed significant $\mathrm{r}$ ratio between students' SDLRS score and students' motivation. While, the analysis on age showed that age of 20 has significant $r$ ratio with students' SDLRS score.

Conclusion: Among age, previous education experience, and culture; students' internal motivation should be considered as important factor for students' SDLRS which will determine their successfulness in learning in medical education. These factors should be regarded as one requirement of students' admission in medical education.
\end{abstract}

Keywords: self directed learning, self directed learning readiness, factors, influence, medical education, medical student

\section{ABSTRAK}

Latar Belakang: Pendidikan kedokteran di Indonesia menganut sistem penerimaan mahasiswa langsung dari lulusan SMA yang selama proses pembelajarannya secara umum sangat dipengaruhi oleh teacher centred-learning. Sebagai bagian dari pendekatan pedagodik pendidikan tinggi, mahasiswa kedokteran diharuskan untuk belajar secara mandiri dan efektif. Self-directed learning (SDL) merupakan suatu aspek penting dari bukti-bukti yang sudah ada terkait dalam pendidikan kedokteran yang akan menjadi aspek penentu kesuksesan mahasiswa dalam belajar. Kesiapan mahasiswa untuk melakukan SDL/self-directed learning readiness (SDLRS) dipengaruhi oleh berbagai faktor, diantaranya adalah motivasi, usia, budaya, dan pengalaman pendidikan sebelumnya. Saat ini proses admisi di Indonesia hanya didasarkan pada uji kognitif/pengetahuan saja. Penelitian ini bertujuan untuk menemukan korelasi antara berbagai faktor yang mempengaruhi SDLRS mahasiwa.

Metode: Penelitian ini menggunakan kuisioner SDLRS yang merupakan suatu alat ukur valid dan reliabel untuk mengukur SLDRS dan mengkorelasikannya dengan berbagai faktor yang mempengaruhinya.

korespondensi: drhikma@ugm.ac.id 
Hasil: Dari 540 kuisioner yang dibagikan, 412 kuisioner dikembalikan. Uji korelasi Spearman menunjukkan korelasi yang signifikan antara skor SLDRS mahasiswa dengan motivasi mahasiswa. Analisis lebih lanjut menunjukkan usia 20 tahun memiliki r-ratio yang signifikan dengan skor SDLRS mahasiswa.

Kesimpulan: diantara usia, pengalaman pendidikan sebelumnya, dan budaya, motivasi internal mahasiswa merupakan hal penting yang mempengaruhi SDLRS mahasiswa yang dapat menentukan kesuksesan mereka dalam belajar di pendidikan kedokteran. Faktor-faktor tersebut dapat dipertimbangkan untuk menjadi suatu persyaratan penerimaan mahasiswa pendidikan dokter baru.

Kata kunci: self directed learning, self directed learning readiness, faktor, pengaruh, pendidikan kedokteran, mahasiswa kedokteran

\section{INTRODUCTION}

Most of medical education use adult learning approach to construct their curriculum as part of higher education. Self-directed learning (SDL) is one students' important ability to success within adult learning approach curriculum. Furthermore, it is also part of lifelong learning ability which is desired for future professional life. ${ }^{1,2}$

As first definition, SDL was mentioned by Knowless (1974) as student's ability to: set their own learning approach, search the appropriate learning strategy, apply their own strategy and evaluate their learning process. ${ }^{3}$ Basically, it is centered on student's autonomy in learning i.e. they regulate their own learning process. Self directed learning readiness (SDLRS) is the extent of students' possession on attitude, ability, and personality of characteristic which necessarily needed in self directed learning. ${ }^{4}$ Students with adequate SDLRS will enhance themselves to have deep learning process. ${ }^{1}$ For example, in problem based learning activities, how students learn deeply would depend on their eagerness to search information as part of students' SDLRS. Therefore, if students have low SDLRS, they would not so interest to add knowledge or search new information. However, there are several factors which could influence students' SDLRS.

As previously known, students' SDLRS were influenced by age, maturation, motivation, previous education experience, and culture. ${ }^{5.8}$ Adult student has bigger responsibility in learning process i.e. being more active to gain new information, set and evaluate their learning goals. In adult education, age and maturation were the most influential factor for students' self directedness. ${ }^{5}$ However, age itself would not be single predictor for students' maturity. Maturity could be defined as psychological stability. However, in what age it would be achieved is still debatable. According to psychological development of learning, seventeen year old student could be considered as a mature age student i.e. being able to responsible on their own decision. ${ }^{9}$ While in a law study, maturity is defined as how a people could decide and be responsible for their own behavior is in between 18 years old until 25 years old. ${ }^{10}$ Being mature could also be defined as mature in thinking process which unfortunately, is not correlated with body maturity. ${ }^{11}$ Nevertheless, there is no specific information about correlation between ages with students' SDL.

The threat on SDLRS laid on students' motivation. According to Loyenss, Magda and Rikers (2008), students' self directed is intertwined with students' internal motivation. ${ }^{2}$ A student with internal motivation is the student who enjoys and engage most of educational activities without need any stimulation. They would be easier to be triggered by pedagogical approach i.e. independency in learning. According to Ryan and Decis' self determination theory (SDT), motivation is categorized into the type and the subject of motivation. ${ }^{12}$ There are two types in SDT which ranges from autonomous until controlled by others, could be also said as internal versus external motivation. The subject itself ranges from individual (own) until collective (e.g. family).

The dilemma is that to be a self directed learner needs self directed learning experiences. SDL 
could be acknowledged as value of learning. ${ }^{13}$ Any previous educational experiences with adult learning approach could implement value of SDL. In this regards, educational experiences with adult learning approach would encourage student to have autonomy in learning. Thus are such educational activities which give freedom, big responsibility, allow creativity and clear goal. ${ }^{13}$ However, how long and deep the experiences which will influence students' SDLRS score are still unknown.

Students' SDLRS are also bounded to cultural aspect. In a previous study on SDLRS by Guglielmino and Guglielmino (2006), the score of SDLRS of employee in organization would have correlation with Hofstede cultural aspect i.e. power distance and individualism. ${ }^{8}$ And Frambach et al.(2012) confirmed that students' self directed learning is influenced by cultural factors such as uncertainty-tradition-hierarchy-achievement. Furthermore another cultural aspect, patriarchal norm could also influence the SDLRS score since it could limit female students to have better chance for study. ${ }^{7}$ As consequences, it will influence development of females' self autonomy which are strongly correlated or bounded with family. ${ }^{14}$ The difference score of SDLRS between female and male students would indicate cultural influences, especially patriarchal norms. ${ }^{15}$ In other words, in society with patriarchal norms, SDL could either influence or be influenced by gender.

Therefore, it is important to understand the nature of students' SDLRS since it would drive the students to desire deep learning process. In regards to medical education in Indonesia that has specific context, there are several things which should be further study: (1) in which age SDL start to develop? (2) Does motivation (subject) has correlation with students' SDLRS? (3) Does educational background influence students' SDLRS? (4) As part culture in Indonesia, do patriarchal norms influence students' SDL? Information on which factors could biggest influence on students' SDLRS would enlighten medical educators in order to construct medical education curricula. This study is aimed to re-explore factors which may have significant correlation with students' self directedness.

\section{METHODS}

This study used quantitative approach. The subject of this study is medical students who were still studying in Faculty of Medicine, Gadjah Mada University (FM UGM). A valid and reliable questionnaire on SDLRS was distributed to all students in Faculty of Medicine, Gadjah Mada University. It was distributed in early academic year with ethical board committee permission. Ten tutorial groups in four academic batches received questionnaires in between JulyAugust 2012. Returned questionnaire considered as willing respondent. A complete answered questionnaire was included to this study.

A questionnaire on SDLRS from Fisher is a revalidated version from the first questionnaire on SDLRS by Guglielmino in 1987. ${ }^{16,17}$ It is constructed from several factors of SDLRS which distributed into forty questions. This study used four frequency Likert scales i.e. rare, often, sometimes, and always. Before distribution of the questionnaire, two FGD (Focus Group Discussion) were held with the researcher in order to recheck the language-validity of the questionnaire. Several questions were edited due to language discrepancies.

Thevalidityand reliability of theSDLRS questionnaire was checked before the analysis of the data. Based on factor analysis, ten components showed Eigen value higher than 1. And as well as mentioned by Fisher and King (2009), those components were extracted into four factors of SDL which are categorized into meta-cognition and learning, time management, eagerness to learn, and systematical learning. ${ }^{16}$ In this study, the reliability test showed that each questions had high \-Cronbach i.e. 0,916. It could be concluded that this questionnaire have high validity and reliability to assess the students' readiness to be self directed learner.

The internal factors of students were asked as part of the students' identity. There were several internal factors asked i.e. birthday, motivation, gender, and previous educational experiences (high-school). Those factors were further categorized.

Based on students' birthday, age was calculated by using year 2012 as base. According to theory, SDL would correlate with age. There are several ages which could be used to see correlation between SDL with ages: 17 , and $18-25$. In this study, 17 
and 20 years old are used as cut of point to see the correlation between ages and students' SDL. With using 17 years old as cut of point, student with age above 17 years old were categorized into point 2 . Subsequently, the students' with age below 17 years old were categorized into point 1 . Thus would be also applied for categorization by using 20 year of age as cut of point.

Motivation was asked by the reason the students' decide in choosing medical education for their further education. This study use SDT of motivation which by type and subject, it divided into three options i.e. (1) own preference, (2) encouraged by parents/relatives/friends, and (3) others (explain). Those three options could be valued as follows first option-category 1 was reflected as high degree of selfness, typed and subject autonomous-individualist, second point-category 2 was reflected as low degree of selfness and typed as controlled by others, and the third point-category 3 was analyzed after data collection which mostly were collectivist.

Educational background were focus on latest education before the students entering medical education i.e. high-school. Based on Indonesian education system, the high-schools could be categorized into two categories i.e. public school and private school. And since there were abroad students with international background, third category was valued as non-Indonesian for those students.

Two type of analysis are conducted, correlation analysis and mean differential analysis. A Spearman analysis was conducted for correlation between agemotivation-high-school and SDLRS score. Then, further regression test was conducted for internal factor which has significant correlation.

For analysis of age, simple correlation was conducted before two correlations test. Subsequently, correlation test was conducted twice to see which age represents high students' SDL.

\section{RESULTS AND DISCUSSION}

In total, 412 from 540 questionnaires were returned to the researcher (76,29\%). From 412 questionnaires, only 404 questionnaires had fully filled answer $(98,06$ $\%)$. The data description is shown in table 1 .

Table 1. The Data Description

\begin{tabular}{|c|c|c|c|c|c|c|}
\hline No & Faktor & Data distribution & \multicolumn{3}{|c|}{ Data categorization } & $\begin{array}{l}\text { Missing } \\
\text { data }\end{array}$ \\
\hline \multirow[t]{2}{*}{1} & \multirow[t]{2}{*}{ Age(s) } & $\begin{array}{l}\mu=19,47 \\
\text { Std de }=2,05 \\
\text { Mo }=17,76\end{array}$ & \multicolumn{2}{|c|}{$\begin{array}{c}<20 \text { years } \\
161\end{array}$} & $\begin{array}{c}\geq 20 \text { years } \\
233\end{array}$ & 9 \\
\hline & & $\begin{array}{l}\text { Median }=19,625 \\
\text { Min }= \\
\operatorname{Max}=25,47\end{array}$ & \multicolumn{2}{|c|}{$\begin{array}{c}<17 \text { years } \\
11\end{array}$} & $\begin{array}{c}\geq 17 \text { years } \\
383\end{array}$ & \\
\hline 2 & Gender & $\begin{array}{l}\text { Mo = girls Median = } \\
\text { girls }\end{array}$ & \multicolumn{2}{|c|}{$\begin{array}{c}\text { Boys } \\
161 \\
\end{array}$} & $\begin{array}{l}\text { Girls } \\
243\end{array}$ & \\
\hline 3 & $\begin{array}{l}\text { High school } \\
\text { background }\end{array}$ & & $\begin{array}{l}\text { Public school, } \\
\text { Indonesia } \\
277\end{array}$ & $\begin{array}{c}\text { Private, } \\
\text { Indonesia } \\
106\end{array}$ & $\begin{array}{c}\text { Non } \\
\text { Indonesian } \\
9\end{array}$ & 12 \\
\hline \multirow{2}{*}{4} & \multirow{2}{*}{ Motivation } & $\begin{array}{c}\text { Mo }=1 \text { (internal } \\
\text { motivation) }\end{array}$ & $\begin{array}{l}\text { Autonomous- } \\
\text { individualist }\end{array}$ & Type-others & $\begin{array}{l}\text { Subject- } \\
\text { collectivist }\end{array}$ & \multirow[t]{2}{*}{12} \\
\hline & & $\begin{array}{c}\text { Median = } 1 \text { (internal } \\
\text { motivation) }\end{array}$ & 276 & 52 & 64 & \\
\hline \multirow[t]{2}{*}{5} & \multirow[t]{2}{*}{$\begin{array}{l}\text { SDLRS Scores } \\
\quad(\mu=120)\end{array}$} & $\begin{array}{c}\mu=120 \\
\text { Std dev }=12,89 \\
\text { Mo }=121\end{array}$ & \multirow{2}{*}{\multicolumn{2}{|c|}{$\begin{array}{l}\text { Below average } \\
\qquad(<120)\end{array}$}} & $\begin{array}{c}\text { Above averages } \\
(\geq 120)\end{array}$ & \\
\hline & & Median = 120 & & & 208 & \\
\hline
\end{tabular}


Twelve (12) students did not entry "reason entering the medical school" which could be seen in table 1. From 400 students, 64 students stated that they had two reasons, such as "me and I want to make my parents happy" which then categorized into category 3.

SDLRS score was categorized into two points based on the achieved mean. According to calculation, the mean of SDLRS score was 120. Then, the SDLRS score was categorized into two point i.e. first point is student with SDLRS score above mean score and second point was student with SDLRS score below mean score.

According to result, there is no significant correlation between age $(r=-0,080, p=0,111,>0,05)$ and high school background $(r=-0,056, p=0,267,>0,05)$ but the result also showed that there is significant correlation between ages of $20(p=0,006,>0,05)$ and motivation $(\mathrm{p}=0,004,>0,05)$ with SDLRS score. While SDLRS score has no significant difference mean on gender $(p=0,215,>0,05)$. It is showed that ages of 20 had $r$ ratio 0,138 and motivation had $\mathrm{r}$ ratio $-0,147$. Thus means that the older students from 20 years old would have better SDRLS score than younger students. While negative $r$ ratio of motivation mean that students with more autonomous-individualist motivation would have better self directedness than students with motivation influenced by others and students with motivation more collectivist. Nevertheless, both of $r$ ratios have low value of correlation.

Both, age and motivation were further tested in order to gain the strength of correlation. According to the regression test, the $R$ ratio of age of $20(R$ ${ }_{20}=0,138$, with $C R_{\text {age of } 20}=1,294$, sig $\left.0,006(<0,05)\right)$ is bigger than $\mathrm{R}$ ration of motivation $\left(\mathrm{R}_{\text {motivation }}=0,122\right.$, $\mathrm{C}_{\text {motivation }}=1,64$, sig $\left.0,016(<0,05)\right)$. It means that age of 20 has bigger influence to students' self directedness than motivation.

Based on the results of this study, students' motivation and age of 20 are the most influential internal factors. Between two factors, age of 20 has bigger influence the students' SDLRS than motivation since the $\mathrm{R}$ ratio of age was bigger than $R$ ratio of motivation.

There is correlation between students' SDLRS score with their internal motivation. Most of students were saying that they would go to medical education because they want it by themselves. Only several of them said that their parents and relatives influenced their decision to choose medicine as their future career. The more students have internal motivationthe more individualist, and the more they would have greater SDLS score since will have greater self determination to decide their action. In addition, students with high internal motivation would develop correct and complete recognition of an object, provide stronger motivation to learn, higher memory retention, and promotes long term storages of knowledge. ${ }^{18}$ According to SDT of motivation, high SDLRS score was explained by high autonomous and self. A high autonomous self-determination student would be able to control their own learning processes, having high meta-cognition. Nevertheless, Hull formulated a formula to explain the need and desire (motive) influence the students' behavior in learning. ${ }^{19}$ Shortly, how students go to the expected outcome in learning, be a self directed learner would be also determined by how big their need to be a doctor. Besides motivation, how intense their motivation and how big the incentive to be a doctor would influence students to have good learning process during their study in medicine. The students who feel being a doctor will give big incentive or see being a doctor will increase self satisfaction would have bigger strength to learn within field study. It is signed since an individual choose medicine as their career path. Hull also mentioned that habit strength would also give influence to the students' behavior in learning, ${ }^{18}$ as it is considered as reinforcement to be a doctor. External reinforcement such as parents' desire could act as constructive reinforcement or opposite. However, thus students who have full autonomy in deciding to learn medicine could determine their own reinforcement. As consequences, we should do more exploration at this point, by in-depth interview following this simple question which we have in this study. We should deepen exploration on their internal motivation which is suitable in medicine i.e. helping other people or external motivation. Thus will give more strength for students to be a good learner, a self directed learner.

Analysis on age of 20 showed that older age from 20 would have bigger SDLRS score. However, if we see on correlation analysis between age and students' SDLRS, it showed that there is no significant 
correlation between age and students' SDLRS. Students with older age from 20 could be assumed having big responsibility, including in learning. As consequences, they would be easier to be nurtured into a self directed learner students. In this study, twenty years of age would be already three (3) years in the medical education program since most of them enter medical school in 17 - 18 years old. There are several experiences within the program which could either enhance or inhibit their maturity in learning. For example, problem based learning (PBL) which is applied by Faculty of Medicine-UGM is one of educational activity which could stimulate students' SDL. ${ }^{2,20}$ In the end, it is still difficult to conclude that age it selves has correlation with students' SDLRS score. This could be also means that several candidates with age under seventeen years old who have potential ability should be helped in order to be a self directed learner.

In most of country, students do not come directly from high-school into higher education. For example, high-school Malaysian student were required to enter preparation program, called pre-college program before they enter higher education; students who will take higher education in Netherland already prepared since they graduate from secondary school, ${ }^{21,22}$ and students in China are same with Netherland, they are prepared from secondary education. ${ }^{23}$ With those older age students, it could be assumed that they are more mature. Therefore, they are more selfdirected than students who come directly from high school such as in Indonesia. In more specific way, they are also more autonomous in making decision which might be part of cultural aspect.

In this study, educational background does not have correlation with students' SDLRS. In this regards, this study only implies on high-school. Thus could means that there is no difference of strategy of learning between public and private school. In another way, this would strengthen argumentation that SDL is a value in learning. ${ }^{13}$ Short period of previous education, high school does not give influence to students' SDL or embed value of SDL to the students. It moves further backward i.e. since they born. In other word, SDL value was embedded since the students in their own family. There are several Indonesia cultural values which could influence the students' SDL and has not been analyzed yet. Furthermore, educational system still implements traditional approach to implement curricula in school until 2013. Only several private schools already implements a new approach for their curricula before 2013 i.e. using an adult learning approach in several topic to trigger students' autonomy in learning. And unfortunately, most of students in this study came from public school which influencing the result of this study.

In order to stimulate students' SDL or achieve the students' autonomy in learning, a program which allow students to recognize their own guidance, to be able to identify their learning goals and plan their learning, and give freedom for the learners learn creatively should be applied into medical education curriculum. ${ }^{13}$ Furthermore, there are several ways to stimulate students' motivation which should be labored by the faculty such as sharing experience on learning with senior students, paneling with expert as senior, etc. Thus should be combined together in order to stimulate the students' SDL within higher education.

The result showed that there is no significant difference on students' SDLRS score between male and female students. Thus indicates that culture, especially patriarchal norms does not have influence to students' SDL. According to Frambach et al (2012), cultural factors such as uncertainty-traditionhierarchy-achievement give challenge for Asian and Middle Eastern students to be a self directed learner. Thus, culture is more regarded common culture as part of learning environment which is very complex in influencing the development of students' SDLRS. In addition, according to study which is held by Claramita (2013), a decision entering a medical school was not majority made based on students' interest, mostly influenced by family of community members or friends. ${ }^{24}$ Furthermore, as part of hierarchy in a community, decision could be made based on pride of being on the higher hierarchy as doctors compare to other profession..$^{24}$ In turn, thus could influence students' motivation. Therefore, those cultural factors should be more explored in learning environment, especially in Asian and Middle Eastern institution since it could either hamper or support development of students' SDLRS. 


\section{CONCLUSION}

Age has correlation and influenced students' SDLRS while elder age students may have better SDLRS. Previous education experience and culture did not prove to have correlation and influence to the SDLRS in this study, such as shorter middle school length also did not influence students' SDLRS. SDLRS may be viewed as a value of learning. Cultures such as patriarch also did not influence students' SDLRS thus there were no difference of SDLRS between male and female students.

Among age, previous education experience, and culture; students' internal motivation should be considered as important factor for students' SDLRS which will determine their successfulness in learning in medical education. These factors should be regarded as one requirement of students' admission in medical education.

\section{SUGGESTIONS}

Students' internal factors, internal motivation have important role for students' SDL. Thus could be used to select new candidate who will entering medical school. A depth interview of motivation would help faculty to help their new students to adapt within their program which applied student centered learning. However, this paper also implies that the development of students' SDLRS could be also influenced by external environments. Therefore, further research on external environment in higher education which related to uncertainty-traditionhierarchy-achievement should be conducted. In the end, students' level of SDLRS should meet encouraging situation in higher education which will enhance the development of the students' SDLRS.

\section{ACKNOWLEDGEMENT}

Thank to Irwan Saputra Batubara, Smitha Dhiya Choirunnisa, my colleague and my faculty for the support in this study.

\section{DECLARATION OF INTEREST}

This study was done independently with institutional support.

\section{REFERENCES}

1. Hmelo-Silver HE. What and How Do students learn? .Educational Psychology Review, 2004;16(3):235-66.

2. Loyens SMM, Magda J, Rikers RMJP. Self directed learning in Problem based learning and its relationship with Self regulated learning. Educ Pshycol Rev, 2008;(20):411-27, DOI 10.1007/s10648-008-9082-7

3. O'Shea E. Self Directed Learning in nurse education: literature review. Journal of Advance Nursing, 2003;43(1):62-70.

4. Fisher MJ, King J, Tague G. Development of a self directed learning readiness scale for nursing education. Nurse Education Today, 2001;21(1):516-25.

5. Mirriam SB. Andragogy and Self Directed Learning: Pillars of Adult Learning Theory. In New Direction for Adult and Continuing Education, 2001;89:3-11.

6. Cullity M. Challenges in understanding and assisting mature age students who participate in alternative entry programs. Australian Journal of Adult Learning, 2006;46(2):175-201.

7. Frambach JM, Driessen EW, Chan LC, Van Der Vleuten CPM. Rethinking globalization of problem based learning: how culture challenges self directed learning. Medical Education, 2012;46:738-47.

8. Guglielmino PJ, Guglielmino LM. Culture, Self Directed Learning Readiness, and Per Capita Income in Five Countries, SAM Advanced Management Journal; 2006, pp 21- 57.

9. Hart D, Atkins R. American Sixteen and seventeen year olds are ready to vote. The ANNALS of the American Academy of Political and Social Science; 2011, pp 201-22.

10. Brian-Hancock C, Casey S. Psychological Maturity of At-Risk Juveniles, Young Adults and Adults: Implications for the Justice System, Psychiatry, psychology, and Law, 2010;17(1):57-69.

11. Orr DP, Brack CJ, Ingersoll G. Pubertal maturation and Cognitive maturity in adolescent. Journal of Adolescent Health Care, 1988;9:273-9.

12. Rudy D, Sheldon KM, Awong T, Tan HH. Autonomy, Culture, and Well Being: The benefit of inclusive autonomy, Journal of Personality, 2007;41:983-1007.

13. Timmins F. Take time to facilitate self directed learning. Nurse Education in Practice, 2008;8:302-5.

14. Helwig CC. The development of personal autonomy throughout culture. Cognitive Development, 2006; 21: 458-73. 
15. Phillips A. When culture means gender: issues of cultural defence in the English courts. Modern Law Review, 2003;66:510-31.

16. Fisher JM, King J. The self-directed learning readiness scale for nursing education revisited: A confirmatory factor analysis. Nurse Education Today, 2009;30:44-8, doi:10.1016/j.nedt.2009.05.020

17. Fisher MJ, King J. The self-directed learning readiness scale for nursing education revisited: A confirmatory factor analysis. Nurse Education Today, 2010;30(1):448.

18. Hidi S. Interest and Its contribution as a mental resource for Learning. Review of Educational Research, 1990;60(4):549-71.

19. Gross R. Part 11: Motivation. Psychology: the Science of Mind and Behavior. $6^{\text {th }}$ edition. London: Hodder Education-An Hancet UK Company; 2012, pp 129. 43.

20. Dolmans DHJM, De Grave W, Wolfhagen IHAP, Van der Vleuten CPM. Problem based learning: future challenges for educational practice and research. Medical Education, 2005;39(7):732-41.

21. Luijkx R, de Heus M. The educational system of the Netherland. 2011 [internet] Downloaded from http://www.mzes.uni-mannheim.de/publications/ misc/isced_97/luij08_the_educational_system_of_ the_netherlands.pdf.

22. Anonym. The Education system in Netherland. [internet] Downloaded from http://www. kempel.nl/DeKempel/Documents/Education SystemInTheNetherlands.pdf.

23. KPMG 2010. Education in China. [internet] Downloaded from https://www.kpmg.de/Topics/23238.htm

24. Claramita M, Nugraheni MDF, van Dalen J, van der Vleuten CPM. Doctor-patient communication in South East Asia: a different culture? Advances in Health Science: Theory and practice, 2013;(18):15-21, DOI: $10.1007 / \mathrm{s} 10459-012-9352-5$. 